\title{
Quantification of single-stranded nucleic acid and oligonucleotide interactions with metal ions by affinity capillary electrophoresis: part I
}

\author{
Alexandra R. Stettler • Valérie Chaurin • \\ Edwin C. Constable $\cdot$ Catherine E. Housecroft . \\ Maria A. Schwarz
}

Received: 3 July 2006/ Accepted: 21 September 2006/Published online: 31 October 2006

(C) SBIC 2006

\begin{abstract}
The interactions between oligonucleotides and inorganic cations have been measured by capillary zone electrophoresis. With increasing concentrations of divalent cations $\left(\mathrm{Ca}^{2+}, \mathrm{Mg}^{2+}, \mathrm{Mn}^{2+}\right.$ and $\left.\mathrm{Ni}^{2+}\right)$ in the running buffer, the migration behavior was evaluated by calculation of the binding constants. Besides these fundamental studies of binding equilibria, different buffer components, tris(hydroxymethyl)aminomethane and 3-( $N$-morpholino)propanesulfonic acid, have been investigated and their effects on metal ion binding quantified.
\end{abstract}

Keywords Affinity capillary electrophoresis .

Buffer · Oligonucleotide · Metal cation

\section{Introduction}

With the completion of the Human Genome Project in 2003 [1], it is critical to understand in detail the mechanisms for the expression of the phenotype from the genotype. It is clear that the modulation and control of DNA expression is achieved through interactions both with large biomolecules and with small molecules or ions. Metal cations are ubiquitous and play an important regulatory role through specific and nonspecific interactions with negatively charged nucleic acids [2-4].

A. R. Stettler · V. Chaurin · E. C. Constable .

C. E. Housecroft · M. A. Schwarz ( $\square)$

Department of Chemistry,

University of Basel,

Spitalstrasse 51,

4056 Basel, Switzerland

e-mail: maria.schwarz@unibas.ch
Solid-state structural characterization of DNA, RNA or oligonucleotide complexes provides unambiguous information about binding modes but caution is required in extending these results to equilibria in solution. There is a demand for rapid and precise analytical methods for the quantification of metal ion-nucleotide interactions under equilibrium conditions.

Methods for the quantification of nucleotide-metal ion interactions can be classified as mixture-based (spectroscopy, densimetry, potentiometry and calorimetry [5-7]) or separation-based (ultrafiltration-centrifugation, chromatography and electrophoresis). Affinity capillary electrophoresis (ACE) is a powerful tool for studying DNA-macromolecule interactions [8-10] and the simplicity, speed and sensitivity of measurement make it attractive for studying DNA-metal ion interactions. Although ACE investigations of metal ionDNA interactions have been reported, only a few studies describe the quantification of complex equilibria. Apparent equilibrium constants have been determined for the interactions of $\mathrm{Ag}^{+}[11], \mathrm{Mg}^{2+}[12], \mathrm{Ca}^{2+}$ [12] and $\mathrm{Fe}^{2+}$ [13] salts with double-stranded DNA.

Two different modes of capillary electrophoresis, electrophoretic mobility shift assay (EMSA) and peak area evaluation, are commonly used. EMSA is best suited to studying low-affinity complexes formed under conditions of rapid equilibration and should be ideal for measuring interactions of labile metal ions with DNA, although all previous studies have utilized peak area analysis. The specific features that make EMSA appropriate to studying DNA-metal ion interactions are (1) the fast kinetics, (2) the moderate binding and (3) the fact that the ionic mobility of the complex is significantly different from that of the DNA itself. 
The different techniques used for studying DNAmetal ion interactions have varying environmental conditions. In particular, measurements have been made in a variety of buffers, most of which contain components (e.g., phosphate, amine) that can coordinate to metal ions and form ternary DNA-metal ionbuffer complexes. Most reported studies of DNAmetal ion interactions have been performed in tris(hydroxymethyl)aminomethane (Tris) which is known to coordinate metal ions. As the ionic mobilities of DNA, DNA-metal ion complexes and DNA-metal ion-buffer ternary complexes will be different, EMSA is an ideal technique with which to probe these interactions in detail.
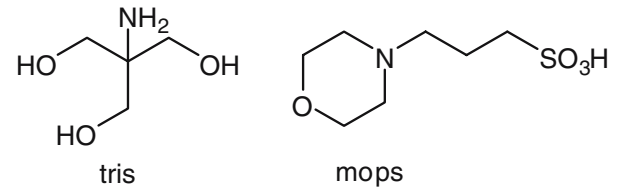

In this paper, we describe the use of ACE for investigating interactions between single-stranded DNA (ss-DNA) or oligonucleotides and metal ions. Apparent aggregation constants for the binding of metal ions by the oligonucleotide have been calculated and the role of the buffer components Tris and 3-( $N$-morpholino)propanesulfonic acid (MOPS; Structure 1) investigated. Varying the oligonucleotide sequence allows us to investigate the selectivity of binding.

\section{Materials and methods}

Chemicals and reagents

All chemicals used were of analytical grade: acrylamide, boric acid, $\mathrm{CuCl}_{2} \cdot 2 \mathrm{H}_{2} \mathrm{O}, \mathrm{FeCl}_{2} \cdot 4 \mathrm{H}_{2} \mathrm{O}$ and $\mathrm{K}_{2} \mathrm{~S}_{2} \mathrm{O}_{8}$ (Acros, Geel, Belgium); dimethyl sulfoxide (DMSO), $\mathrm{MnCl}_{2} \cdot 4 \mathrm{H}_{2} \mathrm{O}, \mathrm{NaOH}$, o-toluic acid (OTA), 3-(trimethoxysilyl)propyl methacrylate, Tris and $\mathrm{ZnCl}_{2}$ (Fluka, Buchs, Switzerland); $\mathrm{FeCl}_{3} \cdot 6 \mathrm{H}_{2} \mathrm{O}$ (Riedel-de Haën, Buchs, Switzerland); $\mathrm{MgCl}_{2}$, MOPS and $N, N, N^{\prime}, N^{\prime}$-tetramethylethylenediamine (Sigma, Buchs, Switzerland); $\mathrm{CaCl}_{2} \cdot 2 \mathrm{H}_{2} \mathrm{O}$ and $\mathrm{NiCl}_{2} \cdot 6 \mathrm{H}_{2} \mathrm{O}$ (Merck, Dietikon, Switzerland). The ss-DNA, 5'-d(TTATTGACGCCGCTTTTTTTTTTT) and the tetranucleotides $\quad 5^{\prime}$-d(AAAA), $\quad 5^{\prime}$-d(GGGG)， $\quad 5^{\prime}$-d(TTTT), $5^{\prime}$-d(CCCC) and $5^{\prime}$-d(TCAG) were obtained purified (high-performance liquid chromatography, HPLC) from Microsynth (Balgach, Switzerland); the 24mer strand was purified again immediately before use by HPLC.

\section{Apparatus}

For the measurements in Tris buffer, a Crystal ATI Unicam model 310 from PrinCE Technology (Emmen, Netherlands) with a Spectra 100 UV detector from Thermo Separation Products (Egelsbach, Germany) was used; data were collected and analyzed with a $\mu$ DAQ AD modifier from Eagle Technology (Cape Town, South Africa). For measurements in MOPS buffer, a PRINCE 500 autosampler 2-LIFT from PrinCE Technology (Emmen, Netherlands) with a Spectra 100 UV detector from Thermo Separation Products (Egelsbach, Germany) was used; data were collected and analyzed with a PowerChrom 280 AD modifier from eDAQ (Denistone East, Australia).

Uncoated fused silica capillary tubing from BGB Analytik (Adliswil, Switzerland) with an internal diameter of $50 \mu \mathrm{m}$, an effective length of $54 \mathrm{~cm}$ and a total length of $67 \mathrm{~cm}$ or an effective length of $33.5 \mathrm{~cm}$ and a total length $84 \mathrm{~cm}$ was used for all measurements. The procedure reported by Hjertén [14] was utilized for preparing a covalently bound layer of $3 \%$ polyacrylamide (PAA) on the surface of the silica capillary to prevent wall absorption.

\section{Method}

Capillaries were conditioned daily by flushing with water for $10 \mathrm{~min}$ at $1,000 \mathrm{mbar}$ and for $10 \mathrm{~min}$ with buffer at 1,000 mbar. Before changing to measurements with a different cation concentration in the buffer, the capillary was washed for $10 \mathrm{~min}$ at 1,000 mbar with the plain buffer. The loading method consisted of three programs: washing for $3 \mathrm{~min}$ at 1,000 mbar with buffer, injection for $0.1 \mathrm{~min}$ at 250 mbar with the sample and separation for up to $20 \mathrm{~min}$ at a potential of $-30 \mathrm{kV}$ (anode detection site) with buffer.

Two different buffers, Tris and MOPS, were used. The Tris buffer was prepared by mixing a solution of Tris with boric acid (solid) to obtain a $\mathrm{pH}$ of 7.4 and dilution to a final Tris concentration of $50 \mathrm{mM}$. For the MOPS buffer, MOPS and $1 \mathrm{M} \mathrm{NaOH}$ were mixed to give a $\mathrm{pH}$ of 7.4 and diluted to a final MOPS concentration of $20 \mathrm{mM}$. The DNA $(0.3 \mathrm{mM})$ and the internal standard (OTA, $10 \mu \mathrm{l}$ saturated solution diluted by $210 \mu \mathrm{l}$ sample solution) were dissolved in water. The metal salts were dissolved in the buffer solution to yield stock solutions that were $10.0 \mathrm{mM}$ in metal ion. These were diluted stepwise by the buffer solutions to $0.5 \mathrm{mM}$. On-capillary detection at $240 \mathrm{~nm}$ (MOPS) or $260 \mathrm{~nm}$ (Tris) at the anode site was used and each measurement was repeated three times for each sample. 


\section{Results and discussion}

\section{Theory of ACE}

ACE can be used to characterize noncovalent intermolecular interactions such as complexation or partition equilibria. We derive here the general relationships between the mobility and equilibria for a system involving a solute $\mathrm{L}$ and a metal ion $\mathrm{M}$ that can form a 1:1 complex ML (Eq. 1):

$\mathrm{M}+\mathrm{L} \rightarrow \mathrm{ML}$

Binding constants $\left(K_{\mathrm{B}}\right)$ can be calculated from an evaluation of the variation of the net mobility of $L$ with metal ion concentration in the running buffer [15].

\section{Derivation of the relationship between $K_{B}$ and $\mu$}

The net mobility $\mu$ is related to the mole fraction $\left(x_{\mathrm{L}}\right)$ and mobility $\left(\mu_{\mathrm{L}}\right)$ of the ligand $\mathrm{L}$ and the mole fraction $\left(x_{\mathrm{ML}}\right)$ and mobility $\left(\mu_{\mathrm{ML}}\right)$ of the complex ML (Eq. 2), where the mole fractions have the conventional definitions in terms of the equilibrium concentration of the ligand and the equilibrium concentration of the complex (Eqs. 3, 4).

$\mu=x_{\mathrm{L}} \mu_{\mathrm{L}}+x_{\mathrm{ML}} \mu_{\mathrm{ML}}$

$x_{\mathrm{L}}=\frac{[\mathrm{L}]}{[\mathrm{L}]+[\mathrm{ML}]}$

$x_{\mathrm{ML}}=\frac{[\mathrm{ML}]}{[\mathrm{L}]+[\mathrm{ML}]}$

Combining Eqs. 2, 3 and 4 yields Eq. 5 in which the net mobility is related to the equilibrium concentrations of the species $\mathrm{L}, \mathrm{M}$ and ML:

$$
\begin{aligned}
\mu & =\frac{[\mathrm{L}]}{[\mathrm{L}]+[\mathrm{ML}]} \mu_{\mathrm{L}}+\left(1-\frac{[\mathrm{L}]}{[\mathrm{L}]+[\mathrm{ML}]}\right) \mu_{\mathrm{ML}} \\
& =\frac{1}{1+[\mathrm{ML}] /[\mathrm{L}]} \mu_{\mathrm{L}}+\frac{[\mathrm{ML}]}{[\mathrm{L}]+[\mathrm{ML}]} \mu_{\mathrm{ML}}
\end{aligned}
$$

For the 1:1 ML complex with stability constant $K_{\mathrm{B}}$ (Eq. 6), it follows that the net mobility is a function of the equilibrium concentration of the analyte $\mathrm{M}$ (Eq. 7):

$$
\begin{aligned}
& K_{\mathrm{B}}=\frac{[\mathrm{ML}]}{[\mathrm{L}][\mathrm{M}]} \\
& \mu=f([M])=\frac{\mu_{\mathrm{L}}+K_{\mathrm{B}}[\mathrm{M}] \mu_{\mathrm{ML}}}{1+K_{\mathrm{B}}[\mathrm{M}]}
\end{aligned}
$$

In the case of more than one metal ion binding to the solute to give complexes $\mathrm{M}_{n} \mathrm{~L}$, the experimental $K_{\mathrm{B}}$ will describe the macroscopic equilibrium and express the sum of every possible interaction between $M$ and L. In the specific case of cooperative binding [15], the net mobility is given by Eq. 8 , and the mobility of the complex, $\mu_{\mathrm{M}_{n} \mathrm{~L}}$ and the apparent stability constant, $K_{\mathrm{B}}$, can be obtained from nonlinear curve fitting:

$\mu=\frac{\mu_{\mathrm{L}}+K_{\mathrm{B}}[\mathrm{M}]^{n} \mu_{\mathrm{M}_{\mathrm{n}}} \mathrm{L}}{1+K_{\mathrm{B}}[\mathrm{M}]^{n}}$

To obtain the net mobility, $\mu$, from capillary electropherograms, the time taken for the analyte and a reference molecule to reach a certain point on the capillary is determined (Eq. 9). Knowing the separation potential ( $U_{\text {sep }}$ in volts), the effective and total length of the capillary ( $l_{\text {eff }}$ and $l_{\text {tot }}$ in centimeters) and the experimental migration times of the analyte and the electroosmotic flow (EOF in square centimeters per volt per second $t_{\text {sample }}$ and $t_{\text {EOF }}$ in seconds), we can calculate $\mu$ using Eq. 9:

$\mu=\frac{l_{\text {eff }} \cdot l_{\text {tot }}}{U_{\text {sep }}}\left(\frac{1}{t_{\text {sample }}}-\frac{1}{t_{\mathrm{EOF}}}\right)$

\section{Migration pattern}

In this section, we comment on the empirical observations of the electropherograms of DNA and oligonucleotides in the presence of metal ions and buffers. All measurements were made at a constant total buffer concentration, although the ionic strength changes as the concentration of metal salt is varied. To calculate the true mobility of the DNA (or oligonucleotide), a noninteracting internal standard has to be added (an inert and preferably neutral molecule, e.g., DMSO). The use of a PAA-coated capillary not only prevents wall absorption, but also suppresses the EOF. In Fig. 1 the influence of added metal ions on the mobility of the reference molecule OTA and indirectly on the magnitude of the EOF is shown. With increasing concentrations of metal ions in the running buffer, the standard apparently migrates faster towards the anode (Fig. 1a). In an independent experiment with OTA and DMSO (an EOF marker) as analytes in the presence of various concentration of metal ions, it was shown that the ionic mobility is not influenced by the metal ion concentration, despite a decrease in the EOF. The decrease in ionic mobility of the DNA or oligonucleotide induced by increased complexation to the metal ion is significantly greater. The reduction in the 


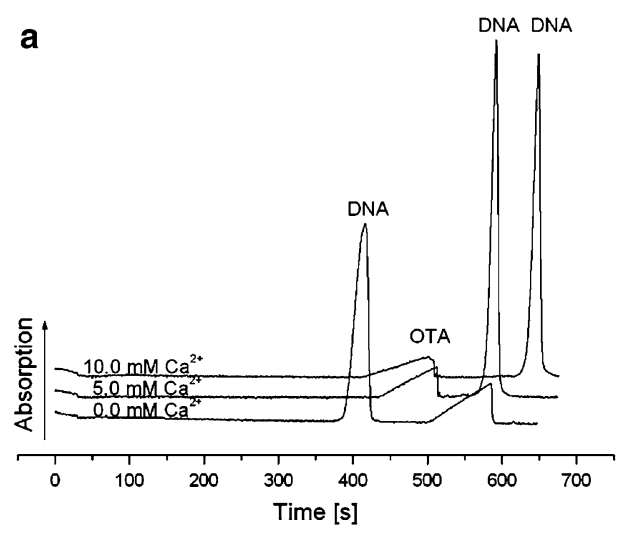

Fig. 1 Capillary electropherograms in a $50 \mathrm{mM}$ tris(hydroxymethyl)aminomethane (Tris), $\mathrm{pH}$ 7.4, 24-base single-stranded DNA $(s s-D N A)$ with $\mathrm{Ca}^{2+}$ in the running buffer and b 20 $\mathrm{mM}$ 3-( $N$-morpholino)propanesulfonic acid (MOPS), $\mathrm{pH} 7.4$,

electrophoretic mobility of the DNA is a measurable quantity that reflects the change of the net DNA charge due to coordination of metal ions. As the metal ion concentration increases, the equilibrium tends towards saturation and the metal complex is the dominant DNA-containing species and the measured ionic mobility is equal to that of the fullly complexed ssDNA strand. Despite the short length of the oligonucleotide (four-base ss-DNA) in Fig. 1b, the change in DNA charge compared with that of the reference molecule is significant.

\section{Buffer influence}

Studies of DNA and oligonucleotides are invariably made in buffer solution; however, the buffer components are not benign and can form adducts with DNA [16], metal ions [17-19] or metal-DNA complexes $[16,20]$. We initially considered Tris as a buffer as it is commonly used as a medium for studies of metal ion-DNA interactions with DNA $[11,12,21]$ and is particularly suitable for capillary electrophoresis experiments owing to its low conductivity [22]. However, transition metal ions form complexes of reasonable stability with Tris [20, 23-29] and ternary M(DNA)(Tris) complexes with oligonucleotides or DNA $[16,20]$. Measured macroscopic $K_{\mathrm{B}}$ values in the presence of a large excess of buffer will relate to mixtures of species. We therefore selected MOPS as our standard buffer for two reasons; firstly, it is known that complexes of MOPS with group 1 and group 2 metal ions are only of marginal stability in aqueous solution, although transition metal complexes are of similar or greater stability than those with Tris $[20,30]$ and, secondly, although the zwitterionic or

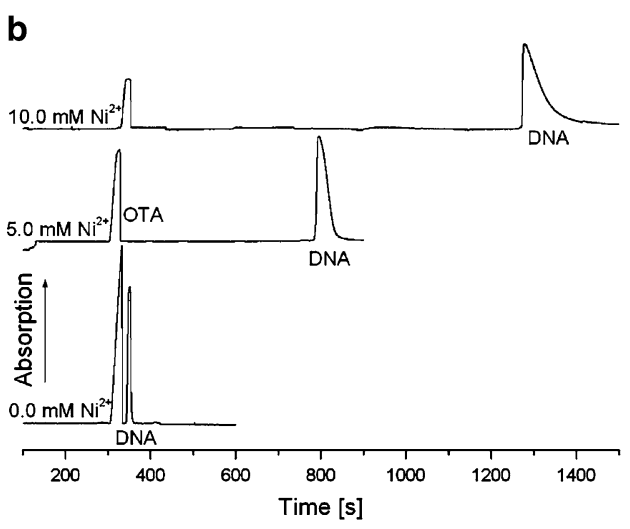

$5^{\prime}$-d(TCAG) with $\mathrm{Ni}^{2+}$ in the running buffer. Separation voltage of $-30 \mathrm{kV} ; o$-toluic acid $(O T A)$ was used as an internal standard; capillary, fused silica coated with $3 \%$ polyacrylamide $(P A A)$

anionic character of MOPS stabilizes the binary complexes with transition metal ions, it also destabilizes ternary complexes with negatively charged oligonucleotides or DNA (Table 1). This prediction has been quantified for ternary complexes of MOPS or Tris with AMP, ADP or ATP, where (1) compared where metal ion-nucleotide complexes, the ternary complexes with Tris are an order of magnitude more stable than those with MOPS and (2) the larger the negative charge on the nucleotide, the less stable is the ternary complex with MOPS [20, 30].

Figure 2 shows that the choice of buffer has a significant effect upon the ionic mobility of the DNAmetal ion solutions and that with a given buffer the behavior is further modulated by the specific metal ion present. The ionic mobility in the absence of metal salt is the same in both buffers, indicating that the same solution species are present-in other words, DNAbuffer complexes are not important in our experimental conditions. In the next section we present the analysis of the electrophoretic behavior in such systems.

Table 1 Binding constants of the 24mer nucleotide measured in 3-( $N$-morpholino)propanesulfonic acid (MOPS) and tris (hydroxymethyl)aminomethane (Tris) buffers

\begin{tabular}{lll}
\hline Metal cation & MOPS & Tris \\
& $K_{\mathrm{B}} \times 10^{5}\left(\mathrm{M}^{-2}\right)$ & $K_{\mathrm{B}} \times 10^{3}\left(\mathrm{M}^{-1}\right)$ \\
\hline $\mathrm{Ca}^{2+}$ & $8.49 \pm 2.24$ & $1.36 \pm 0.10$ \\
$\mathrm{Mg}^{2+}$ & $7.75 \pm 1.75$ & $1.75 \pm 0.10$ \\
$\mathrm{Mn}^{2+}$ & $5.70 \pm 1.63$ & $1.81 \pm 0.14$ \\
$\mathrm{Ni}^{2+}$ & $9.85 \pm 1.75$ & $1.41 \pm 0.92$ \\
\hline
\end{tabular}

Experimental conditions as in Fig. 2. Note that the apparently large differences in stability are, in part, a function of the different dimensionality of the $K_{\mathrm{B}}$ values 
Fig. 2 Running buffer: red $50 \mathrm{mM}$ Tris buffer ( $\mathrm{pH} 7.4$ ), black $20 \mathrm{mM}$ MOPS buffer (pH 7.4); sample 24mer ssDNA, 5'-d(TTATTGACGC CGCTTTTTTTTTTT); separation voltage $-30 \mathrm{kV}$; with $3 \%$ PAA, $67 \mathrm{~cm} / 54 \mathrm{~cm} /$ $50 \mu \mathrm{m}$ (red; total length/ effective length/diameter), $84 \mathrm{~cm} / 33.5 \mathrm{~cm} / 50 \mu \mathrm{m}$ (black) capillary, fused silica coated

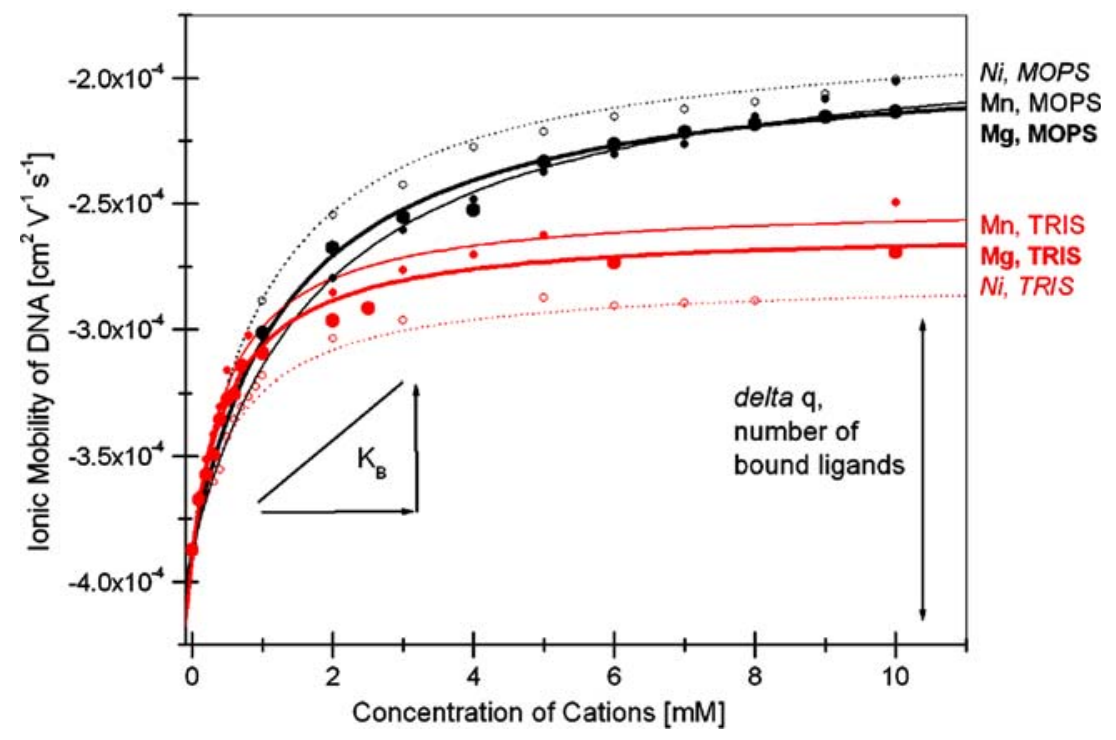

$\mathrm{DNA}+\mathrm{M}+(\mathrm{BUFF}) \rightleftarrows \mathrm{M}(\mathrm{BUFF})(\mathrm{DNA})$

Detailed analysis and quantification

of electrophoretic behavior

$K_{\mathrm{B}}^{\prime}=\frac{[\mathrm{M}(\mathrm{DNA})(\mathrm{BUFF})]}{[\mathrm{M}][\mathrm{DNA}][\mathrm{BUFF}]}$

tween the two buffers, we need, in principle, to discuss the various possible equilibria in a solution containing DNA, metal and buffer (Eqs. 10, 11, 12, 13, 14, 15, 16):

$\mathrm{M}+(\mathrm{BUFF}) \rightleftarrows \mathrm{M}(\mathrm{BUFF})$

$\mathrm{M}+\mathrm{DNA} \rightleftarrows \mathrm{M}(\mathrm{DNA})$

$\mathrm{M}(\mathrm{BUFF})+\mathrm{DNA} \rightleftarrows \mathrm{M}(\mathrm{BUFF})(\mathrm{DNA})$

$(\mathrm{BUFF})+\mathrm{DNA} \rightleftarrows(\mathrm{BUFF})(\mathrm{DNA})$

$\mathrm{M}+(\mathrm{BUFF})(\mathrm{DNA}) \rightleftarrows \mathrm{M}(\mathrm{BUFF})(\mathrm{DNA})$

$\mathrm{M}(\mathrm{BUFF})+(\mathrm{BUFF})(\mathrm{DNA}) \rightleftarrows \mathrm{M}(\mathrm{BUFF})(\mathrm{DNA})$

$\mathrm{M}(\mathrm{DNA})+(\mathrm{BUFF}) \rightleftarrows \mathrm{M}(\mathrm{BUFF})(\mathrm{DNA})$

Our experiments allow the determination of the overall stability constant $K_{\mathrm{B}}^{\prime}$ for the formation of the ternary (or binary) complex (Eq. 17) and require no detailed knowledge of the speciation of the starting metal ion-buffer solution or the nature of DNA-buffer complexes. The overall stability constant $K_{\mathrm{B}}^{\prime}$ is simply the product of the usually quoted stability constants for Eqs. 11 and 16 [20, 30]:
The mobility is given by Eq. 18 (cf. Eq. 2), with the assumption that DNA-buffer complexes make a minimal contribution [16]:

$\mu=x_{(\mathrm{DNA})} \mu_{(\mathrm{DNA})}+x_{\mathrm{M}(\mathrm{DNA})(\mathrm{BUFF})} \mu_{\mathrm{M}(\mathrm{DNA})(\mathrm{BUFF})}$

The overall binding constant $K_{\mathrm{B}}^{\prime}$ (Eq. 16) is related to the mobility by Eq. 19, which is simply an extension of Eq. 7 to the ternary system. The buffer is in large excess and the concentration remains essentially constant at all concentration of the metal. For multiple metal binding sites it necessary to substitute $[\mathrm{M}]^{n}$ and $[\mathrm{BUFF}]^{n}$ in Eq. 19:

$\mu=f([\mathrm{M}])=\frac{\mu_{\mathrm{DNA}}+K_{\mathrm{B}}^{\prime}[\mathrm{M}][\mathrm{BUFF}] \mu_{[(\mathrm{DNA})(\mathrm{M})(\mathrm{BUFF})]}}{1+K_{\mathrm{B}}^{\prime}[\mathrm{M}][\mathrm{BUFF}]}$

We now consider the case of the binding of nickel(II) in detail and demonstrate the true stoichiometry of the reaction. At higher metal ion concentrations, the mobility in Tris has reached a plateau value and in MOPS is close to this. The plateau mobility represents the mobility of the metal ion saturated DNA. Excess nickel(II) will be predominantly present as nickelbuffer complexes $(10 \mathrm{mM} \mathrm{Ni(II),} 50 \mathrm{mM}$ Tris, $17 \%$ $\mathrm{Ni}(\mathrm{aq})^{2+}, 46 \% \mathrm{Ni}(\text { Tris })^{2+}, 37 \% \mathrm{Ni}(\text { Tris })_{2}{ }^{2+}[20,23,24$, 26, 28, 29]; $10 \mathrm{mM} \mathrm{Ni(II),} 20 \mathrm{mM}$ MOPS, 7\% Ni(aq) $)^{2+}$, 
$\left.93 \% \mathrm{Ni}(\mathrm{MOPS})^{2+}[30,31]\right)$ and the nickel(II) complexes could be binary or ternary, with the former favored by MOPS and the latter by Tris.

In the case of the Tris buffer, the change in mobility from zero metal ion concentration to the plateau value $\Delta \mu$ is $1.0 \times 10^{-4} \mathrm{~cm}^{2} \mathrm{~V}^{-1} \mathrm{~s}^{-1}$. The less negative value of $\mu$ confirms that the nickel-DNA complex has a less negative charge than the DNA. The absolute value of the mobility is given by Eq. 20 (where $q$ is the charge, $r$ is the hydrodynamic radius and $\eta$ is the viscosity of the medium):

$\mu=\frac{q}{6 \pi r \eta}$

The change in mobility is given in Eq. 21 , where $\Delta q$ is the change in charge of the DNA between the metal-free and metal-saturated forms, making the assumptions that the viscosity of the solution remains the same [32] and that the hydrodynamic radii of the DNA and the DNA-nickel complexes are the same [33]:

$$
\Delta \mu=\frac{\Delta q}{6 \pi r \eta}
$$

Solving Eq. 21 using the experimental value for $\Delta \mu$ in Tris of $1.0 \times 10^{-4} \mathrm{~cm}^{2} \mathrm{~V}^{-1} \mathrm{~s}^{-1}$ and $0.9 \times 10^{-3} \mathrm{~kg} \mathrm{~m}^{-1} \mathrm{~s}^{-1}$ for $\eta$ [34], we obtain Eq. 22:

$\Delta q=1.7 \times 10^{-10} r C$

As Tris is a neutral ligand, regardless of the formation of ternary or binary complexes the change in charge per nickel ion bound is +2 (at $\mathrm{pH} 7.4$, hydroxy complexes can be discounted) and $\Delta q$ is simply $2 n$, where $n$ is the number of nickel ions bound. Using a value of $1.1 \mathrm{~nm}$ for the hydrodynamic radius of a single strand [33], we obtain $\Delta q=1.9 \times 10^{-19} \mathrm{C}$, and dividing by the elementary charge of $1.6 \times 10^{-19} \mathrm{C}$, we obtain a difference between the DNA and nickel-DNA complex of 1.2 charge units. In view of the gross assumptions made in this calculation, together with the expectation that the ss-DNA conformation is likely to be complex, possibly with a minihairpin at the $5^{\prime}$ $\mathrm{d}(\mathrm{CGCCG})$ motif, this is a minimum value and we can state that the nickel-DNA complex in Tris buffer has a 1:1 metal-DNA stoichiometry, although we cannot state whether it is a binary or a ternary complex.

A comparison of the mobility shifts for the nickelDNA system in Tris and MOPS buffers is most informative. In MOPS buffer the plateau value for $\Delta \mu$ is about twice that for Tris buffer, which means that the change in charge is also twice that in Tris. On the basis of a 1:1 complex in Tris, we conclude that in MOPS either four $\{\mathrm{Ni}(\mathrm{MOPS})\}^{+}$or two $\mathrm{Ni}^{2+}$ units are coordinated to the DNA. The former is unreasonable, in terms of both speciation and the known destabilisation of MOPS ternary complexes and we conclude that the saturated species in MOPS buffer is a $\mathrm{Ni}_{2}$ (DNA) species although small amounts of the ternary species could be present. The difference in behavior is probably partly steric in origin-Tris acts as a terdentate $\mathrm{N}, \mathrm{O}, \mathrm{O}$ donor $[35,36]$ and the molecular volume of a $\left\{\mathrm{Ni}\right.$ (Tris) $\left.\left(\mathrm{H}_{2} \mathrm{O}\right)_{2}\right\}$ moiety is $158 \AA^{3}$ compared with $100 \AA^{3}$ for $\left\{\mathrm{Ni}\left(\mathrm{H}_{2} \mathrm{O}\right)_{5}\right\}$.

\section{Tetranucleotides—-specific interactions}

In the previous section we discussed the behavior of a 24 mer ss-DNA with metal ions and analyzed the interactions with nickel(II) in detail. It is not appropriate to discuss the site of metal ion binding in detail. In an attempt to investigate metal-DNA interactions in a more systematic way, we studied the behavior of the tetranucleotides 5'-d(AAAA), 5'-d(GGGG), 5'$\mathrm{d}(\mathrm{CCCC}), 5^{\prime}$-d(TTTT) and 5'-d(TCAG). Rather surprisingly, very little is known about the solution or the solid-state conformation of tetranucleotides in the absence of a complementary strand. In particular, the tetranucleotides we selected are expected to be singlestranded and flexible in solution and certainly will not adopt a DNA duplex structure [37, 38].

Metal ions can stabilize or destabilize the duplex forms of A-DNA or B-DNA [13]. There are a number of different potential binding sites for metal ions at the DNA: the most likely are the phosphate groups and N7 of the purine bases adenine and guanine (Scheme 1a, b) $[7,39]$. The higher electronegativity of $\mathrm{N} 7$ of guanine is responsible for stronger interaction with cations than other nitrogen donors within the heterocycles [40, 41]. Hard cations prefer to bind to the phosphate group of the backbone, whereas softer cations, such as transition metal dications, preferentially interact with the nitrogen donor of the purine bases. Binding of the metal ions may be direct or indirect through water molecules, and coordinated water ligands can provide additional bridging interactions to other bases [7, 39, 42, 43]. It has been shown that nickel(II) has a particular preference for binding to the N7 terminal or outlooped guanine sites of B-form DNA [39, 44-53]. Although at $\mathrm{pH}>8$, transition metals can generate $\mathrm{M}$-DNA in which cations replace the imino protons (Scheme 1c), this is not likely to be relevant under our experimental conditions [54].

Uniquely, in the case of $5^{\prime}-\mathrm{d}(\mathrm{GGGG})$, there is also the possibility of forming a guanine quadruplex 

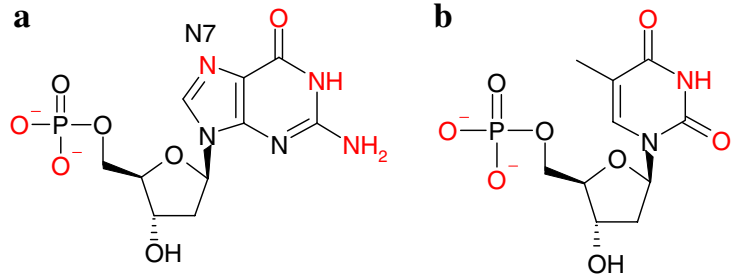

c
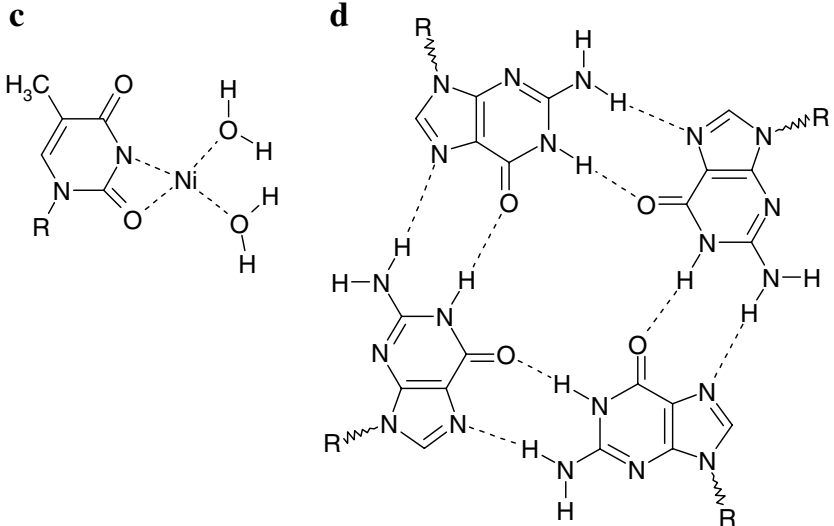

Scheme 1 a Guanosine monophosphate, b thymidine monophosphate, c M-DNA (thymine) with an imino group and d guanine quadruplex. In $\mathbf{a}$ and $\mathbf{b}$ the potential donor atoms are indicated in red

through Hoogsteen hydrogen bonding which can be further stabilized by binding a metal ion such as $\mathrm{K}^{+}$ [55]. The most stable structures are obtained with potassium or strontium ions and the stabilizing influence is in the sequence $\mathrm{K}^{+} \gg \mathrm{Na}^{+}>\mathrm{Rb}^{+}>\mathrm{Cs}^{+} \gg \mathrm{Li}^{+}$ and $\mathrm{Sr}^{2+} \gg \mathrm{Ba}^{2+}>\mathrm{Ca}^{2+}>\mathrm{Mg}^{2+}$ [56]. It has been reported that $\mathrm{Li}^{+}$[57] and transition metal dications [58] destabilize the quadruplex structure. We now describe the electrophoretic behavior of the tetranucleotides in the presence of various metal ions.

Figure 3 gives an overview of the migration patterns of the various tetranucleotides in the presence of metal cations. The starting point for the discussion is the mobility in the absence of added metal ions (although, of course, sodium is present in the buffer). The four tetranucleotides $5^{\prime}$-d(AAAA), 5'-d(CCCC), $5^{\prime}$-d(TTTT) and $5^{\prime}-\mathrm{d}(\mathrm{TCAG})$ all have a mobility of $-3.0 \pm 0.05 \mathrm{~cm}^{2} \mathrm{~V}^{-1} \mathrm{~s}^{-1}$, whereas $5^{\prime}$-d(GGGG) has a mobility of $-4.0 \mathrm{~cm}^{2} \mathrm{~V}^{-1} \mathrm{~s}^{-1}$. The electrophoresis provides clear evidence for the presence of different species in the solution of $5^{\prime}$-d(GGGG) from the species in solutions of the other tetranucleotides $\left(\mathrm{N}_{4}\right)$. However, it is possible to comment further on the nature of the solution species. The increased mobility of the $5^{\prime}$-d(GGGG) species results from an increase in the charge-to-hydrodynamic radius ratio compared with that of a single-stranded tetranucleotide. From Eq. 20 it follows that the ratio of the mobility of
$5^{\prime}$-d(GGGG) $\left(\mathrm{G}_{4}\right)$ to $\mathrm{N}_{4}$ is given by Eq. 23 (assuming the viscosity of the solutions is constant):

$\frac{\mu\left(\mathrm{G}_{4}\right)}{\mu\left(\mathrm{N}_{4}\right)}=\frac{q\left(\mathrm{G}_{4}\right)}{q\left(\mathrm{~N}_{4}\right)} \frac{r\left(\mathrm{~N}_{4}\right)}{r\left(\mathrm{G}_{4}\right)}$

For a $\mathrm{G}_{n}$ multiplex, assuming a common hydrodynamic radius of single-stranded $\mathrm{G}_{4}$ and $\mathrm{N}_{4}$, we obtain Eq. 24:

$\frac{\mu\left(\mathrm{G}_{4}\right)}{\mu\left(\mathrm{N}_{4}\right)}=\frac{4}{3}=n \frac{r\left(\mathrm{~N}_{4}\right)}{r\left(\mathrm{G}_{4}\right)}$

The best solution is for a quadruplex with $n=4$, where the calculated ratio $r\left(\mathrm{~N}_{4}\right) / r\left(\mathrm{G}_{4}\right)$ of $1 / 3$ is close to that calculated from a simple model based on cylinders of fixed radius (1/2.414) and that observed in solid-state structural determinations of sequences with guanine quadruplexes.

The pyrimidine tetranucleotides $5^{\prime}-\mathrm{d}(\mathrm{CCCC})$ and $5^{\prime}$-d(TTTT) show essentially similar behavior with extrapolated plateau values in the presence of $\mathrm{Mg}^{2+}$ or $\mathrm{Ca}^{2+}$ being reached at lower metal ion concentrations than with $\mathrm{Ni}^{2+}$. Extrapolation to the final plateau mobilities is not reliable for $\mathrm{Ni}^{2+}$, but the data (in particular the estimated $\Delta q$ ) are compatible with the binding of a single metal ion per nucleotide. We suggest that the binding site is the phosphate, compatible with the higher stability of the complexes with the harder $\mathrm{Mg}^{2+}$ and $\mathrm{Ca}^{2+}$ ions.

The trend for the pyrimidine tetranucleotides is reversed for $5^{\prime}$-d(AAAA), with the mobility reaching a plateau at lower metal ion concentrations in the presence of $\mathrm{Ni}^{2+}$, indicating a greater stability for the nickel complex compared with the calcium and magnesium complexes. The curves for $\mathrm{Mg}^{2+}$ and $\mathrm{Ca}^{2+}$ are very similar to those for the pyrimidine tetranucleotides. These observations are compatible with binding of calcium or magnesium at the phosphate and nickel at the purine although the $K_{\mathrm{B}}$ values are the same within experimental error (Table 2).

Very different behavior is observed for the tetranucleotide $5^{\prime}$-d(TCAG), where the change in mobility in the presence of $\mathrm{Ni}^{2+}$ is double that for $\mathrm{Ca}^{2+}$ and $\mathrm{Mg}^{2+}$ and the extracted stability constant for the nickel complex is significantly larger than that for calcium or magnesium. As the mobility of $5^{\prime}$-d(TCAG) in the absence of added metal ion is the same as that of $5^{\prime}$ $\mathrm{d}(\mathrm{CCCC}), 5^{\prime}$-d(AAAA) or $5^{\prime}$-d(TTTT), the different behavior in the presence of nickel is not due to different starting structures of the tetranucleotides. This behavior is almost certainly associated with the binding 
Fig. 3 Mobility shifts of tetranucleotides $(0.3 \mathrm{mM})$ in the presence of various concentrations of metal salts (20 mM MOPS running buffer). a $5^{\prime}$-d(AAAA), b $5^{\prime}$-d(GGGG), c $5^{\prime}$ $\mathrm{d}(\mathrm{CCCC})$, d $5^{\prime}$-d(TTTT) and e $5^{\prime}$-d(TCAG) all in the presence of various concentrations of $\mathrm{Mg}^{2+}$ (red), $\mathrm{Ca}^{2+}$ (black) and $\mathrm{Ni}^{2+}$ (blue). f A comparison of the five tetranucleotides in the presence of $\mathrm{Ni}^{2+}$
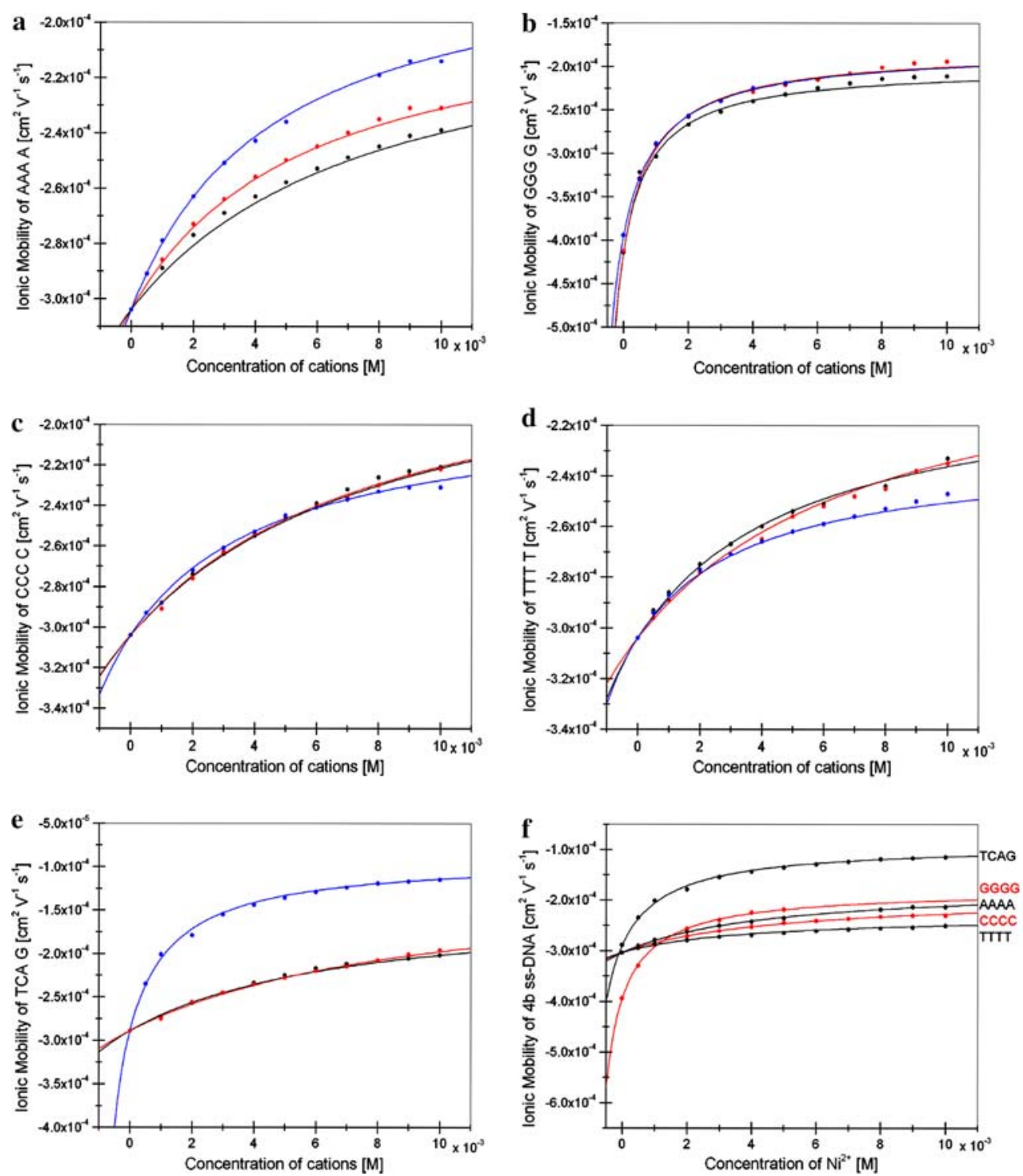

of nickel to the N7 of the terminal guanine. We tentatively suggest that a second nickel is interacting with phosphate.

In the case of $5^{\prime}$-d(GGGG) the behavior is very different. We have already commented upon the difference in mobility in the absence of metal salt being compatible with the presence of the guanine quadruplex in solution. The three metal ions $\mathrm{Ni}^{2+}, \mathrm{Mg}^{2+}$ and $\mathrm{Ca}^{2+}$ all give very similar changes in mobility and the change in charge to radius ratio is significantly larger than is observed with the other nucleotides. The change in mobility is $2 \times 10^{-4} \mathrm{~cm}^{2} \mathrm{~V}^{-1} \mathrm{~s}^{-1}$ at the plateau value

Table 2 The interactions between the single-stranded DNA and $\mathrm{Ca}^{2+}, \mathrm{Mg}^{2+}, \mathrm{Ni}^{2+}$ and $\mathrm{Mn}^{2+}$ with $20 \mathrm{mM}$ MOPS at pH 7.4

\begin{tabular}{llll}
\hline & \multicolumn{1}{l}{$K_{\mathrm{B}}$} & \\
\cline { 2 - 4 } & $\mathrm{Ca}^{2+}$ & $\mathrm{Mg}^{2+}$ & $\mathrm{Ni}^{2+}$ \\
\hline $5^{\prime}$-d(AAAA) & $128 \pm 14 \mathrm{M}^{-1}$ & $177 \pm 8 \mathrm{M}^{-1}$ & $220 \pm 10 \mathrm{M}^{-1}$ \\
$5^{\prime}$-d(CCCC) & $115 \pm 7 \mathrm{M}^{-1}$ & $118 \pm 9 \mathrm{M}^{-1}$ & $204 \pm 16 \mathrm{M}^{-1}$ \\
$5^{\prime}$-d(GGGG) & $19.7 \pm 5.54 \times 10^{5} M^{-2}$ & $17.4 \pm 4.19 \times 10^{5} M^{-2}$ & $18.7 \pm 3.80 \times 10^{5} M^{-2}$ \\
$5^{\prime}$-d(TTTT) & $221 \pm 26 \mathrm{M}^{-1}$ & $187 \pm 32 \mathrm{M}^{-1}$ & $261 \pm 20 \mathrm{M}^{-1}$ \\
$5^{\prime}$-d(TCAG) & $140 \pm 13 \mathrm{M}^{-1}$ & $104 \pm 8 \mathrm{M}^{-1}$ & $10.1 \pm 2.52 \times 10^{5} M^{-2}$ \\
\hline
\end{tabular}

Experimental conditions as in Fig. 1. Value in italics were calculated on the basis of a 1:2 stoichiometry (ligand to metal) 
and using a value for the hydrodynamic radius of the quadruplex of $3 \times 1.1 \mathrm{~nm}$ (see earlier), the calculated $\Delta q$ value is 4 , strongly indicating that the quadruplex binds a metal ion at each of the two termini.

Finally, it is useful to compare the behavior of the five tetranucleotides with the single metal ion, $\mathrm{Ni}^{2+}$ (Fig. 3f). This clearly shows that (1) the overall changes in mobility for the three tetranucleotides $5^{\prime}$-d(CCCC), $5^{\prime}$-d(TTTT) and $5^{\prime}-\mathrm{d}($ AAAA) are very similar, (2) that the changes in mobility for $5^{\prime}$-d(TCAG) and $5^{\prime}$ $\mathrm{d}(\mathrm{GGGG})$ are very similar and (3) the overall change for $5^{\prime}-\mathrm{d}(\mathrm{TCAG})$ and $5^{\prime}-\mathrm{d}(\mathrm{GGGG})$ is twice that of $5^{\prime}$ $\mathrm{d}(\mathrm{CCCC}), 5^{\prime}$-d(TTTT) or $5^{\prime}$-d(AAAA). These observations are in accord with the proposals above.

\section{Conclusion}

We have shown that ACE may be used to investigate the interactions of oligonucleotides with metal ions. Initial studies have indicated that the choice of buffer solution is critical and that the commonly used Tris and MOPS buffers bind transition metal ions by introducing additional equilibria into the solution phase. The observed binding affinities of oligonucleotides for group 2 and transition metal ions may be rationalized in terms of a two-site binding model involving phosphate and nitrogen donors in the nucleotide and quantified using limiting mobility values. Anomalous results with $5^{\prime}$-d(GGGG) are interpreted in terms of a quadruplex. In short, ACE methods provide a great deal of information in rapid experimental procedures and we are currently investigating environmental variables in detail to determine whether the method may be used for the extraction of "conventional" binding constants for metal ion-DNA interactions. Principally chip measurements with short separation lengths of $2.5 \mathrm{~cm}$ are feasible; however, more suitable buffer components (UV permeability) for a higher sensitivity have to be found to measure a complete titration row and thus more precise $K_{\mathrm{B}}$ values.

Acknowledgements We would like to thank Shimadzu Corporation and the University of Basel for their kind support. We also thank Yorck-Michael Neuhold for constructive discussions. Partial funding for this project was provided by Swiss National Science Foundation, grant numbers 200021-103812/1 and 20C321101122.

\section{References}

1. Human Genome Program (2003) Genomics and its impact on science and society: a 2003 Primer. US Department of Energy

2. Sigel H (ed) (1979) Metal ions in biological systems, vol 8. Nucleotides and derivatives: their ligating ambivalency
3. Sigel A, Sigel H (eds) (1996) Metal ions in biological systems, vol 32. Interactions of metal ions with nucleotides, nucleic acids, and their constituents

4. Sigel A, Sigel H (eds) (1996) Metal ions in biological systems, vol 33. Probing of nucleic acids by metal ion complexes of small molecules

5. de la Fuente M, Hernanz A, Navarro R (2004) J Biol Inorg Chem 9:973-986

6. Kankia BI (2004) Biopolymers 74:232-239

7. Sigel H, Griesser R (2005) Chem Soc Rev 34:875-900

8. He XY, Ding YS, Li DZ, Lin BC (2004) Electrophoresis 25:697-711

9. Heegaard NHH (2003) Electrophoresis 24:3879-3891

10. Guijt-van Duijn RM, Frank J, van Dedem GWK, Baltussen E, Schalkhammer T (2001) Electrophoresis 22:1247-1247

11. Arakawa H, Neault JF, Tajmir-Riahi HA (2001) Biophys J 81:1580-1587

12. Ahmad R, Arakawa H, Tajmir-Riahi HA (2003) Biophys J 84:2460-2466

13. Ouameur AA, Arakawa H, Ahmad R, Naoui M, TajmirRiahi HA (2005) DNA Cell Biol 24:394-401

14. Hjertén S (1985) J Chromatogr A 347:191-198

15. Rüttinger H-H (2003) In: Neubert RHH, Rüttinger $\mathrm{H}-\mathrm{H}$ (eds) Affinity capillary electrophoresis in pharmaceutics and biopharmaceutics. Dekker, New York, pp 23-43

16. Stellwagen NC, Bossi A, Gelfi C, Righetti PG (2000) Anal Biochem 287:167-175

17. Sokołowska M, Bal W (2005) J Inorg Biochem 99:1653-1660

18. Taha M, Khalil MM, Mohamed SA (2005) J Chem Eng Data 50:882-887

19. Good NE, Winget GD, inter W, Connolly TN, Izawa S, Singh RMM (1966) Biochemistry 5:467-477

20. Fischer BE, Haring UK, Tribolet R, Sigel H (1979) Eur J Biochem 94:523-530

21. Ouameur AA, Tajmir-Riahi H-A (2004) J Biol Chem 279:42041-42054

22. Shihabia SK (2000) Electrophoresis 21:2872-2878

23. Hall JL, Liden TM, Swisher JA, Brannon DG (1962) Inorg Chem 1:409-413

24. Bai KS, Martell AE (1969) J Inorg Nucl Chem 31:1697-1707

25. Brignac PJ, Mo C (1975) Anal Chem 47:1465-1466

26. Bologni L, Sabatini A, Vacca A (1983) Inorg Chim Acta 69:71-75

27. Canepari S, Carunchio V, Schina R (1999) Polyhedron 18:3263-3267

28. Rao GN, Murthy CSR, Prakash A (1982) Indian J Chem A 21:203-205

29. Forsling W (1978) Acta Chem Scand A 32:857-865

30. Azab HA, Orabi AS, El-Salam ETA (2001) J Chem Eng Data 46:346-254

31. Anwar Z, Azab H (1999) J Chem Eng Data 44:1151-1157

32. Okafo GN, Brown R, Camilleri (1991) J Chem Soc Chem Commun 864-866

33. Fujimoto BS, Miller JM, Ribeiro NS, Schurr JM (1994) Biophys J 67:304-308

34. Kell GS (1972) In: Franks F (ed) Water-a comprehensive treatise. Plenum, New York, p 406

35. Ivarsson GJM (1982) Acta Crystallogr Sect B 38:1828-1831

36. Zeng M-H, Liang H, Zeng R-Y, Yi X-H, Yu K-B (2002) Acta Chim Sin 60:784-788

37. Packer MJ, Dauncey MP, Hunter CA (2000) J Mol Biol 295:85-103

38. Dixit SB, Beveridge DL, Case DA, Cheatham TE, Giudice E, Lankas F, Lavery R, Maddocks JH, Osman R, Sklenar H, Thayer KM, Varnai P (2005) Biophys J 89:3721-3740 
39. Egli M (2004) Curr Opin Chem Biol 8:580-591

40. Abrescia NGA, Huynh-Dinh T, Subirana JA (2002) J Biol Inorg Chem 7:195-199

41. Sponer J, Sabat M, Gorb L, Leszczynski J, Lippert B, Hobza P (2000) J Phys Chem B 104:7535-7544

42. Soler-López M, Malinina L, Subirana JA (2000) J Biol Chem 275:23034-23043

43. Chiu TK, Dickerson RE (2000) J Mol Biol 301:915-945

44. Valls N, Usón I, Gouyette C, Subirana JA (2004) J Am Chem Soc 126:7812-7816

45. Gao YG, Sriram K, Wang AH (1993) Nucl Acid Res 21:4093-4101

46. Abrescia NGA, Malinina L, Subirana JA (1999) J Mol Biol 294:657-666

47. Subirana JA, Abrescia NGA (2000) Biophys Chem 86:179189

48. Abrescia NGA, Malinina L, Fernández LG, Hunyh-Dinh T, Neidle S, Subirana JA (1999) Nucleic Acid Res 27:1593-1599
49. Yang XI, Robinson H, Gao YG, Wang AH-J (2000) Biochemistry 39:10950-10957

50. De Meester P, Goodgame DML, Skapski AC, Smith BT (1974) Biochim Biophys Acta 340:113-115

51. Collins AD, De Meester P, Goodgame DML, Skapski AC (1975) Biochim Biophys Acta 116:2958-2971

52. Sigel H, Massoud SS, Corfu NA (1994) J Am Chem Soc 116:2958-2971

53. Labiuk SL, Delbaere LTJ, Lee JS (2003) J Biol Inorg Chem $8: 715-720$

54. Hartzell B, McCord B (2005) Electrophoresis 26:1046-1056

55. Simonsson T (2001) Biol Chem 382:621-628

56. Guschlbauer W, Chantot JF, Thiele D (1990) J Biomol Struct Dyn 8:491-511

57. Sen D, Gilbert W (1992) Methods Enzymol 211:191-199

58. Blume SW, Guarcello V, Zacharias W, Miller DM (1997) Nucleic Acid Res 25:617-625 